\title{
English Language Teaching in Rural Areas: A New Challenge for English Language Teachers in Colombia*
}

\author{
BERTHA RAMOS HOLGUÍN" \\ bertha.ramos@uptc.edu.co \\ JAHIR AGUIRRE MORALES \\ jahir.aguirre@uptc.edu.co
}

Recepción: 30 de marzo de 2015

Aprobación: 18 de septiembre de 2015

Forma de citar este artículo: Ramos Holguín, B., \& Aguirre Morales, J. (2016). English Language Teaching in Rural Areas: A New Challenge for English Language Teachers in Colombia. Cuadernos de Lingüística Hispánica, (27), 209-222.

* $\quad$ Artículo de reflexión que da cuenta de algunos de los resultados del proyecto de investigación: "Towards the Exploration of Pre service Teachers Identities as Language Learners and Future Teachers: a Case Study”, código SGI 1521, financiado por la Dirección de Investigaciones de la Universidad Pedagógica y Tecnológica de Colombia, Colombia.

** Holds an M. A. in Applied Linguistics from Universidad Distrital Francisco José de Caldas. She is an associate professor at Universidad Pedagógica y Tecnológica de Colombia. She belongs to the research group TONGUE.

*** Holds an M. A. in English Didactics from Universidad de Caldas. He is an assistant professor at Universidad Pedagógica y Tecnológica de Colombia. He belongs to the research group TONGUE. 


\begin{abstract}
Most English teachers in Colombia are reluctant to work in rural schools due to several challenges that they may encounter. The purpose of this article, which is based on the results of research studies conducted in Boyacá and Santander (Colombia) about English teaching in rural areas, is to show some of the reasons why teachers do not select a job in rural zones. It also suggests some strategies to overcome these issues. Finally, the authors discuss some of the implications for teachers and stakeholders.
\end{abstract}

Key words: Colombian rural education, English language teaching, English teachers

\title{
La enseñanza de la lengua inglesa en áreas rurales: un nuevo desafío para los docentes de inglés en Colombia
}

\section{Resumen}

La mayoría de profesores de inglés en Colombia no desean trabajar en colegios rurales debido a los desafíos que este tipo de contexto representa. El propósito de este artículo, que está basado en los resultados de investigaciones llevadas a cabo en Boyacá y Santander (Colombia) en relación con la enseñanza de inglés en zonas rurales, es mostrar algunas de las razones por las cuales los profesores no ven las zonas rurales como una opción para trabajar. El artículo también propone algunas alternativas para sobrepasar estos inconvenientes. Finalmente, los autores discuten algunas implicaciones para los profesores y la comunidad educativa.

Palabras Clave: Educación rural en Colombia, enseñanza de inglés, profesores de inglés 


\section{L'enseignement de la langue anglaise dans des zones rurales: un nouvel défi pour les professeurs d'anglais en Colombie}

\section{Résumé}

La majorité des professeurs d'anglais en Colombie ne veulent pas travailler dans des écoles rurales, dû aux défis que ce type de contexte représente. Le propos de cet article, qui se base sur les résultats de recherches menées à bien à Boyacá et à Santander (Colombie) par rapport à l'enseignement de l'anglais dans de zones rurales, est celui de montrer quelques-unes des raisons pour lesquelles les professeurs ne voient pas les zones rurales comme une option de travail. L'article propose aussi quelques alternatives pour dépasser ces inconvénients-là. Finalement, les auteurs discutent quelques implications pour les professeurs et la communauté éducative.

Mots clés: Education rurale en Colombie, enseignement d'anglais, professeurs d'anglais.

\section{o ensino da língua inglesa em áreas rurais: um novo desafio para os docentes de inglês na Colômbia}

\section{Resumo}

A maioria de professores de inglês na Colômbia não deseja trabalhar em colégios rurais devido aos desafios que este tipo de contexto representa. 0 propósito deste artigo, que está baseado nos resultados de pesquisas levadas a cabo em Boyacá e Santander (Colômbia) em relação com o ensino de inglês em zonas rurais, é mostrar algumas das razões pelas quais os professores não veem as zonas rurais como uma opção para trabalhar. 0 artigo também propõe algumas alternativas para superar estes inconvenientes. Finalmente, os autores discutem algumas implicações para os professores e a comunidade educativa.

Palavras Chave: Educação rural na Colômbia, ensino de inglês, professores de inglês 


\section{Introduction}

The occupation of rural areas in Colombia has changed over the last few decades. Colombia was, by the middle of the last century, a country with half of its population living in rural areas, whereas now only a fifth of its total population lives in rural settlements. Thus, as rural areas have decreased, most schools' models have been developed with a focus on urban areas, and as Moulton (2001) explains a schooling model developed in an urban context is not always relevant to a rural setting.

Development policies have mostly focused on urban areas; the pervasive poverty, the armed conflict and the inclusion of Colombia in the global market without the heavy subsidies of industrialized countries have produced a decrease in the rural population over the years. Today, based on data from the census conducted by the National Administrative Statistics Department DANE (2014), it is estimated that only one fifth of the population lives in rural areas. The average income of the rural population is half that of those living in urban areas. The rate of people living under the poverty line is around $50 \%$ in urban areas and $70 \%$ in rural areas. This rate of poverty analyzed by Parra-Peña, Ordoñez and Acosta (2013) as "Poverty and extreme poverty in rural areas -at $64.1 \%$ and $22.1 \%$ respectively far exceeded the urban settings" (p. 1). The degree of literacy varies greatly between urban and rural areas. In urban areas the degree of illiteracy is six percent while in rural areas it is $21 \%$ which is extremely high and constitutes an unequivocal proof of the abysmal differences in the quality of life between the different zones of the country (Vásquez, 2013). In addition to the previous facts, UNESCO (2011) states that in rural primary schools, the dropping out rate is higher compared to urban zones. The rate of school attendance in secondary schools has increased (Perfetti, 2005), but the quality of the education in rural areas, measured in standardized exams, is far below the national average.

These are some of the causes why many Colombian teachers do not see rural areas as a priority to work in. Furthermore, Curz-Arcila (2013) argues that rural language teachers usually have unbalanced sociocultural, economic, ethnic and political conditions. Besides that, as stated by Brown (2003), a rural teacher has to be multitasking to teach multiple grades, plan extracurricular activities and fit in the educational environment. Education is 
challenging in rural areas everywhere. Problems are similar because the rural context, in spite of cultural and environmental differences, shares features that are problematic for the execution of successful education policies. One of the most common problems in rural areas is the recruitment of teachers, which is a key element in improving the quality of education. There are various reasons why enrolment of teachers is challenging. As a matter of fact, UNESCO (2011) pinpoints it is hard to hire teachers who fit into the particularities rural education has. This article explores some challenges for teachers in rural zones, and it also proposes some suggestions in order to overcome these challenges. Thus the purpose of this paper is to provide teachers with information on the pertinent implications of being an English teacher in a rural setting.

\section{Challenges for Teachers in Rural Zones}

Isolation, cultural adaptation, misconceptions that rural families have about education, motivation, infrastructure, and violence are some of the shortcomings which inhibit English teachers from working in rural areas. First, isolation in both, a social and a professional context, plays an important role when choosing a place to work. Most teachers come from urban areas and it is very difficult for them to adapt to the sometimes very isolated environment of rural areas; also, some of them will miss having stimulating academic interactions with peers. To this respect Mulkeen (2005) asserts that teachers in rural areas also find cultural isolation.

Another problem, which is along the same line, is cultural adaptation to the rural environment, in terms of daily routines and the culture of the community and the students (Barley and Briham, 2005). In addition, teachers must be qualified to teach multiple subjects, and most of the time they are qualified in just one or two of them, which does not represent a problem in urban areas, but poses a problem when the rural teacher has to manage subjects as diverse as math, sciences, arts, English as a foreign language and social sciences. Finally, the fact that in some rural communities teachers have to teach multi-level classes is not attractive to the prospective teacher, not even mentioning salaries. The previous issues were undertaken by Castle (1995) when reflecting upon teachers reluctance to work in rural areas.

Another issue related to this is the ideas families have about the education of their children. Some families do not see the relevance of learning more than basic reading, writing and math. Furthermore, automatic promotion in primary school affects the final academic level of the students. "All students are promoted to upper classes without subject ability. To such students it becomes difficult to cope up with the syllabus of English at graduation level" (Tayade, 2013, p. 22). Since the students in these schools do not obtain 
high scores in standardized tests, their children are at a disadvantage for going to college -not to mention the difficulties, sometimes insurmountable, of sending a young man or woman away to an expensive city or town. Also, some of the curricula are made in urban centers with a focus on an urban context, so the content and treatment of it are often not relevant for students.

Rural students can also lack motivation. The importance of English as a global language remains abstract to students that hardly travel outside their county; usually they only have contact with the nearest town, so English is a rarity not connected to their lives. This is closely related to what has been called the affective filter hypothesis (Majid, Muhammad, Puteh, and Bunari, 2008). If the students are motivated and confident, have a very positive self-image, and do not have high anxiety levels, then the learning process will be optimal. If not, the process will not succeed.

Infrastructure is another general problem. Although Plan Decenal de Educacion Rural en Colombia 2006-2016 (The Colombian ten-year Plan for Rural Education 20062016), suggests that rural school are in need of appropriate infrastructure, didactic and technological resources for a better learning ,rural schools do not have the implements and equipment to teach classes with relative success. Moulton (2001) says that while in many cases building materials and furniture can be locally supplied, instructional materials are not available. These resources include not only textbooks but also the visual materials that decorate classrooms and stimulate learning, as well as simple scientific lab equipment, radios, and other audio-visual equipment that have become standard parts of many classrooms. English classrooms and laboratories should be the rule, not the exception.

Colombia has had an armed conflict for decades and the security situation is critical in many zones both in the countryside and in urban areas. Violence has affected rural and urban areas in different ways. While in urban areas street drugs are the main cause of violence among children and teenagers, in rural areas it is the armed conflict which causes the recruitment of minors and massive displacements that affect the permanence of children in schools. UNDP (2011) remarks that illegal groups such as guerrillas, drug dealers and paramilitaries have spread violence to gain land which has caused more displacement of population in rural settings. Sometimes entire schools have to be closed because it is not safe for students or teachers to be there.

\section{Towards a Dialogical Proposal}

Some of the strategies that could be useful to overcome the aforementioned problematic situations are a syllabus that includes the cultural particularities of rural areas, 
the proper introduction of teachers to the community, the participation of the community in the planning process, the access to learning resource centers, and local support.

In order to increase students' motivation, programs must be designed in away that takes into account the particularities of rural areas. It is a source of demotivation for students to read and study topics that are totally unrelated to their daily lives. Nowledge must be seen as something real and tangible (Shor, 1987). Without dismissing national standards of quality, content must be adapted by region so that students and members of the community can see how schooling is important and relevant to their lives. English as a foreign language is no exception. Content must be adapted by region, emphasizing the cultural particularities of the zones where they are being taught. In this sense, Romero (2007) suggests the use of place-based education. He asserts that teachers can take into account local resources that help learners to apply knowledge in real and meaningful contexts. In the same line of thought, Avery and Kassam (2011) mention that children have a substantial bank of knowledge that is not validated in the classroom. These authors highlight the need to create a link between students' local knowledge and their classroom learning. "Such linkage involves recognition by the educational system of the value, legitimacy, and utility of this rural knowledge to the educational curriculum" (Avery and Kassam, 2011, p. 5).

English teachers must have a proper introduction to the teaching techniques in rural areas and also to the pedagogical models that have been proven to be most effective in that zone. Teachers must be introduced to the community's relevant ethnographic information in order to smoothly enter into the community, avoiding conflicts that could arise by not having cultural information about the group in question. At this point, it is important to examine and consider the communicative and social interaction rules of the community in order to understand interactions and be able to assertively explain differences in rhetoric or interaction exchanges. For example, teachers must be aware that if children are not allowed to question the authority of adults in the community, it is going to be very difficult for them to answer direct questions to teachers; therefore, the teacher must make these differences explicit so that students can participate without feeling that they are violating appropriateness rules within their social group (Passasung, 2003).

The planning must be done with community participation; it is very important to take into account what the expectations of families and students are, so that they do not feel that their academic programs are being designed by urban centers without their participation. It is crucial that planners learn from communities and actually include their opinions and feedback in the programs. In other words, education in rural areas should account for pertinence. "Pertinence in education has to do with the development of proposals which take into account the rural context in order to avoid exporting traditional education 
designed for urban settings into rural contexts" (Ministerio de Educación Nacional, 2012, p. 15) Along with improving children's classes, schools must be transformed into cultural centers where communities have the opportunity to have English classes for adults, as well as literacy classes and all kind of cultural events so that the school becomes the center of the community (Moulton, 2001).

Like all policies, to be effective, this needs local support; therefore, it is important to have the English programs explained to the community so that they support them in all levels. These policies have to permeate the community through real agents like teachers. These teachers fit into the rural community once they show solidarity to the community. It means, teachers have to become members and contributors of the community if they want the community value and support their academic plans (Cheers, 1992). If the school becomes a center for development, it is going to be easier to gain support from the community (Moulton, 2001).

It is also significant to design materials and activities that value rural cultures and that emphasize multicultural values as a positive asset. Ramos, Aguirre and Hernandez (2012) carried out a pedagogical experience that aimed at integrating eleventh graders' rural context through the design of curricular units. The authors mention that aspects such as students's sense of cultural belonging and intercultural understanding were enhanced. Developing a sense of belonging and healthy pride while still respecting other cultures will help students and families realize the importance of learning about other languages and cultures.

It is very important to coordinate with local universities, "which can perceive the realities of their local contexts" (Ramos and Vargas, 2012, p. 30) to establish academic alliances with rural schools and local education administrations. These associations will help raise the English level of both students and teachers in rural areas. Universities and local education administrations, along with school principals, can coordinate teaching practices for pre-service teachers in rural schools. In fact, as suggested by Cardenas, Gonzalez and Alvarez (2010) universities should be in charge of preparing not only preservice but also in-service teachers. This will be beneficial for the student teachers, since they will have a real experience in a challenging environment and will have the opportunity to contribute to the development of rural areas in their departments. In fact, Barley and Brigham (2008) assert that the preparation of prospective rural teachers is not only the responsibility of the hiring school, but also this responsibility relies on the institutions with undergraduate teaching programs. 
Parents do not necessarily know how to help students excel in academic duties. This is especially true of parents in both rural and urban low-income communities. It is important to hold school lectures for parents on how to motivate students, how to help them organize their time, how to improve the conditions where students do homework or read, and above all, about the importance of learning a foreign language in today's world. Another way to unite home and school is by having teachers develop their own teaching material. "This may help teachers close the gap between home and school and then, involve parents and engaged students' families in the school context" (Ramos and Aguirre, 2014, p. 138).

On the use of English in the classroom in rural areas, there are some considerations to be taken into account. Provided teachers are fully qualified to speak all the time in English, speaking in English should be the rule in English classes, but the difficulties of understanding what the teacher says could actually increase the demotivation of students, so it is important to use -with moderation - the L1 in the classroom, while knowing that the primary language of the class should be English. That means that the teacher should know how and when to use the L1: "In case of rural students, mother tongue is one of the very effective tools of ELT. Translation into the mother tongue also helps a teacher in simplifying the nuances of English" (Bhushan, 2011). The teacher must use English as much as possible, since in rural areas, in most cases, she or he will be the only model for the student, since the exposure to English outside the classroom is minimal, if there is any at all.

Although it has been said that the main language used in the classroom should be English, it is important to note that the level of the English used with students must be appropriate. In other words, very complex structures and sophisticated vocabulary as well as talking at a fast rate must be avoided when addressing beginners and intermediate students. "English lecturers are suggested to teach English subject in simple and familiar English language and thereby create interest among the students toward English subject" (Betageri, 2013).

Wherever and whenever possible, it is ideal to have a Learning Resource Center, since it has been proven that students do improve after they have used this kind of resource: "a Learning Resource Centre gives a tremendous ignition to the desire of a learner to speak English and provides the ambience of English. The learner's accent, pronunciation, stress, tone, etc. are controlled and modified according to the standard pattern" (Bhushan, 2011).

Barrera-Osorio, Maldonado and Rodriguez, (2012) explained that the Ministry of TIC's in Colombia started in 2000 with a program called Computers for Education. The first phase of this programs consisted of equipping each public educational institution in Colombia with a computer for each twenty students enrolled. It could be perceived that in a 
rural school with sixty students only three computers were allocated, not even mentioning a school with lower population. In this sense, Barrera and Linden (2009) evaluated the program and they found out that there were not significant educational gains. Nevertheless, if the institution cannot afford a Learning Resource Center, even the simplest aids, like CDs and DVDs, can make a difference with children and young adults. If the exercises are complemented with the proper activities, improvement will occur. Even showing films in English with English subtitles once or twice a week will improve reading and listening skills in students.

\section{Conclusions}

The main objective of this paper was to provide teachers and stakeholders with an overview of the challenges teachers may face while teaching in rural areas. Some of these encounters were isolation, cultural adaptation, and misconceptions rural families have about education, motivation, infrastructure, and violence. The authors argue that many urban teachers are not willing to take the challenge of facing schools in rural areas because of the previous issues.

The text continued by mentioning some alternative ideas to implement in order to help teachers move smoothly into rural settings, namely: (1) inclusion in the syllabus of cultural particularities in rural areas, (2) the proper introduction of teachers to the community, (3) the participation of the community in the planning, (4) local support and (5) the access to learning resource centers. Finally, it indicates that teaching programs should introduce pre-service teachers to the rural context as part of the teaching experiences to avoid misconceptions about rural schooling. This paper ends by calling policy makers to acknowledge teachers working in rural areas.

\section{Discussion and Pedagogical Implications}

Teaching programs should insert pre-service teachers into the rural context as part of their teaching experiences. It is a fact that teaching programs in Colombia carry out diverse teaching practices during their programs. If student- teachers have the opportunity to face the rural reality, they may be more willing to teach in those scenarios.

Another significant implication to consider is that pre-service teachers should be familiarized with the positive aspects of working in a rural zone so that they can make informed professional choices. In a study related to rural teachers, Boylan and McSwan (1998) found out that $80 \%$ of in-service teachers mentioned the advantages of working in a rural area. In fact, "There emerged a profile of a professionally satisfied, community integrated, family oriented teacher who enjoyed the rural lifestyle and environment" (Boylan 
and McSwan, 1998, p. 49). Considering the previous issue, it is of paramount importance to help pre-service teachers avoid negative attitudes towards country life. Then, as stated by Campbell and Yates (2011, p. 2), "it may be entirely feasible to encourage potential country teachers through attempting to change the way in which they perceive the advantages of country teaching and country life".

The Colombian government through the National Bilingual Program (NBP) called now "Program for Strengthening the Development of Competencies in a Foreign Language.' has implemented the program English for Colombia ECO (2011). This program follows a communicative approach and is based on New School Methodology to help educators and learners achieve high standards in education. However, it is a young program to perceive its impact in the community. According to Centro Virtual de Noticias de la Educacion, 2014 in the first semester of 2014 the Ministry of National Education in Colombia with the help of the Educational Development Center (EDC) Inc, started and evaluation process of the material developed for the ECO program. However, as pointed out by Cardenas (2006), Guerrero (2008), Sanchez and Obando (2008), Usma (2009), Gonzalez (2010), Guerrero (2010), more efforts and changes are needed to improve the conditions of disadvantaged areas in order to achieve the goals established in the (NBP).

Finally, it is essential that policy makers acknowledge the efforts that teachers are making to succeed in the teaching of English in rural zones. It is fundamental to listen to the needs, beliefs and experiences expressed in teachers' voices so that they can feel recognized as asserted by Pennycook (2001) and Wink (2000). Such recognition should take the form of easy access to professional development program. Monk (2007) suggests that professional development programs should take place in the rural areas teachers work, and they should focused on teachers' experiential knowledge so that they value being part of the community they work in (Bonilla and Cruz-Arcila, 2013). Also attractive salaries may help alleviate the lack of teachers willing to work in rural settings.

\section{References}

Avery, L. M., \& Kassam, K. A. (2011). Phronesis: Children's local rural knowledge of science and engineering. Journal of Research in Rural Education, 26(2), 1-18.

Barrera-Osorio, F., \& Linden, L. (2009). The use and misuse of computer in education: evidence from a randomized experiment in Colombia. Policy Research Working Paper Series 4836, the World Bank. 
Barrera-Osorio, F., Maldonado, D., \& Rodríguez, C. (2012). Calidad de la educación básica y media en Colombia: Diagnóstico y propuestas. Serie Documentos de Trabajo $N^{\circ} 126$. Bogotá, Colombia: Universidad del Rosario.

Barley, Z., \& Brigham, N. (2005). Preparing Teachers to Teach in Rural Schools. United States: The Ball State University.

Betageri, G. (2013). Impact of English language teaching on the communication skills of rural students. International Journal on English Language and Literature , 1(1), 36-49.

Bonilla, S., \& Cruz-Arcila, F. (2013). Sociocultural factors involved in the teaching of English as a foreign language in rural areas of Colombia: an analysis of the impact on teachers' professional development. Research in Teacher Education, 3(2), 28-33.

Boylan, C., \& McSwan, D. (1998). Long-staying rural teachers: Who are they? Australian Journal of Education, 42, 49-65.

Bhushan, R. (2011). Challenging but enjoyable English Language teaching in rural areas: A case study of BPS Women University, Khanpur Kalan, Haryana. ELT Voices, 44-50.

Brown, D. L. (2003). Challenges for Rural America in the 21st Century. University Park, PA: Pennsylvania State University Press.

Campbell, A. M., \& Yates, G. C. R. (2011). "Want to be a country teacher? No, I am too metrocentric". Journal of Research in Rural Education, 26(4), 1-12.

Cárdenas, M. L., González, A., \& Álvarez, J. (2010). El desarrollo profesional de los docentes de inglés en ejercicio: algunas consideraciones conceptuales para Colombia. Folio, 31, 49-68.

Castle, E. N. (1995). The Changing American Countryside: Rural People and Places. Kansas: University Press of Kansas.

Centro virtual de Noticias de la Educación CVNE (2014). Docentes del sector rural se forman en inglés como lengua extranjera gracias a estrategia de MinEducación. Retrieved from: http://www.mineducacion.gov.co/cvn/1665/w3-article-33971.html

Cruz- Arcila, F. (2013). Accounting for difference and diversity in language teaching and learning in Colombia. Educ. Educ, 16(1), 80-92.

Cheers, B. (1992). Some thoughts on multiskilled rural welfare practictioners. Rural Society, 2 (1), 25-42.

DANE. (2014). DANE. Censo General del 2005. Retrived from: https://www.dane.gov.co/index.php/ poblacion-y-registros-vitales/censos/censo-2005 
González, A. (2010). English and English teaching in Colombia: tensions and possibilities in the expanding circle. Routledge Handbook of World Englishes. London: Routledge.

Guerrero, C. (2008). Bilingual Colombia: what does it mean to be bilingual within the framework of the National Plan of Bilingualism? PROFILE Issues in Teachers' Professional Development, $9,27-45$.

Guerrero, C. (2010). The portrayal of EFL teachers in official discourse: the perpetuation of disdain. PROFILE Issues in Teachers' Professional Development, 12(2), 33-49.

Majid, N. A., Muhammad, F., Puteh, F., \& Bunari, G. (2008). Instilling interest in English among ESL students in rural community: A collaboration between higher learning institution and a community in Malaysia. Malaysia: Johor Ed.

Ministerio de Educación Nacional. (2007). Aportes del Plan Nacional Decenal de Educación 2006-2016 en Educación Rural. Recuperado de: http://www.plandecenal.edu.co/ $\mathrm{html} / 1726 / \mathrm{w} 3$-propertyvalue-45850.html

Ministerio de Educación Nacional (MEN). (2011). English for Colombia ECO. Bogotá, Colombia: MEN.

Ministerio de Educación Nacional. (2012). Manual para la formulación y ejecución de planes de educación rural. Bogotá, Colombia: Ministerio de Educación Nacional.

Monk, D. (2007). Recruiting and retaining high-quality teachers in rural areas. The Future of Children, 17, 155-174.

Moulton, J. (2001). Improving education in rural areas: Guidance for rural development specialists. For Charles Maguire: The World Bank.

Mulkeen, A. (2005). Teachers for Rural Schools: A Challenge for Africa. Working paper. Biennale on Education in Africa (Libreville, March 27-31, 2006). Association for the Development of Education in Africa

Parra-Peña, I., Ordóñez, L., \& Acosta, C. (2013). Policies for Bridging the Urban-Rural Gap in Colombia International Center for Tropical Agriculture. Retrived from:http://dapa.ciat. cgiar.org/wp-ontent/uploads/2014/08/policy_brief7_policies_bridging_urban_rual_ colombia1.pdf

Passasung, N. (2003). Teaching English in an "acquisition poor environment": An ethnographic example of a remote Indonesian EFL classroom. PhD Dissertation, University of Sydney, Department of linguistics, Sydney.

Pennycook, A. (2001). The Politics of Pedagogy. In A. Pennycook (Ed.), CriticalApplied Linguistics: A Critical Introduction (pp. 114-140). New Jersey: Lawrence Erlbaum Associates 
Perfetti, M. (2005). Colombia aprende. Retrived from: http://www.colombiaaprende.edu.co/html/ mediateca/1607/article-73482.html

Ramos, B., \& Aguirre, J. (2014). Materials development in the Colombian context: Some considerations about its benefits and challenges. HOW, A Colombian Journal for Teachers of English, 21(2), 134-150.

Ramos, B., Aguirre, J., \& Hernández, C. (2012). A Pedagogical experience to Delve into Students Sense of Cultural Belonging and Intercultural Understanding in a Rural School. HOW Journal, 19, 123-145.

Ramos, B., \& Vargas, N. (2012). Algunas Reflexiones sobre el Plan Nacional de Bilinguismo, sus Impactos y Realidades en el departamento de Boyacá. Enletawa Journal. 5, 21-34.

Romero, E. (2007). Personal narrative and the formation of place-identity in northern New Mexico: Applied research in rural education. Unpublished doctoral dissertation, The University of Arizona, Tucson.

Sánchez, A., \& Obando, G. (2008). Is Colombia ready for Bilingualism? PROFILE Issues in Teachers' Professional Development, 181- 195.

Shor, I. (1987). Freire for the classroom: A Source Book for Liberatoru teaching. Porsthmouth, NH: Boyton/Cook Heinemann.

UNESCO. (2011). Improving the conditions of teachers and teaching in rural schools across African countries. Addis Ababa, Ethiopia: UNESCO-IICBA.

Usma, J. (2009). Globalization and language and education reform in Colombia: a critical outlook. Ikala: Revista de Lenguage y Cultura, 14, 19-42.

Tayade, S. (2013). Teaching English in rural Colleges: realities and remedies. Confluence. 330-335.

UNDP (United Nations Development Program). (2011). Colombia Rural: Razones para la esperanza. Bogotá, Colombia: Nantional Human Development Report.

Vásquez, C. (2013). Analfabetismo en Colombia. Retrived from: http://alfabetismomundo. blogspot.com/2013/02/analfabetismo-en-colombia.html

Wink, J. (2000). Critical pedagogy: Notes from the real world. NY: Addison Wesley, Longman. 